\title{
In Vitro Myotrophic Effect of Serum Kappa Chain Immunoglobulins from a Patient with Kappa Light Chain Myeloma and Muscular Hypertrophy
}

\author{
Christine Delaporte,* Bruno Varet,‡ Michel Fardeau," Dominique Nochy,§ and André Ract" \\ * Laboratory of Neuromuscular Biology and Pathology, Institut National de la Santé et de la Recherche Médicale Unité 153 and Centre \\ National de la Recherche Scientifique, Équipe de Recherche; ¥Department of Hematology, Hôpital Cochin; §Department of Pathology, \\ Hôpital Broussais; and "Department of Medicine, International Hôpital de la Cité Universitaire, Paris, France
}

\begin{abstract}
Muscle hypertrophy due to enlarged muscle fibers was accompanied by kappa light chain myeloma in a 62-yr-old man. Immunofluorescence showed kappa light chain deposits around muscle fibers. We hypothesized that a circulating growth factor may be involved in the pathogeny of this muscular hypertrophy. Patient serum cultured with muscle cells showed that $(a)$ the patient's serum exhibited a trophic effect on human muscle cells in culture, (b) this trophic effect increased the differentiation and did not influence the proliferation of human muscle cells, and (c) the fraction of the patient's serum immunoadsorbed on antihuman kappa chain antibodies exhibited the same in vitro effect on the muscle cells, whereas the fraction immunoadsorbed on antihuman lambda chain antibodies did not. These results support the hypothesis that the patient's kappa light chains have a specific enhancing effect on human muscle cell differentiation, perhaps leading to an acquired muscular hypertrophy.
\end{abstract}

\section{Introduction}

A rapidly progressive and generalized skeletal muscle hypertrophy is often reported in pathological conditions related to endocrine disorders and, when the muscle enlargement is more focal, to neurologic diseases. In a few cases, the enlargement of the muscle mass is due to amyloid deposits and is thus a pseudohypertrophy (1-8). We have recently reported the case of a patient with a kappa light chain myeloma associated with an acquired muscular hypertrophy free of endocrinological or neurological pathology and without amyloid deposits (9). Thin deposits of kappa light chains around the muscle fibers did not account for the muscular hypertrophy. However, they may provide a possible stimulating effect on the growth of striated muscle fibers. In this paper, we studied the in vitro effect of the patient's serum and kappa light chain Ig on muscle cells in culture.

\section{Methods}

Case report. The history of the patient follows, in brief. A Caucasian male, born in 1917, first exhibited symptoms of muscular hypertrophy on the right leg in March of 1979. Muscular hypertrophy rapidly involved the muscles of the upper and lower members and the trunk. He was first

Address reprint requests to Dr. Delaporte, INSERM U 153, 17 rue du Fer-à-Moulin, 75005 Paris, France. 1986.

Received for publication 27 August 1985 and in revised form 9 May

J. Clin. Invest.

(c) The American Society for Clinical Investigation, Inc.

0021-9738/86/10/0922/06 \$1.00

Volume 78, October 1986, 922-927 hospitalized in November of 1979. The prominent finding was a huge hypertrophy of all skeletal muscles (Fig. 1). Cardiac muscle remained apparently intact ( $x$-ray examination, electrocardiography, and echocardiography). Routine hematological and biochemical investigations, including plasma muscle enzymes, were normal. Endocrine and polyneuropathic disorders were ruled out. The patient was discharged without diagnosis. In May of 1981, the patient was again hospitalized. The muscular enlargement had progressed (e.g., an additional $6 \mathrm{~cm}$ at the leg level), reducing the patient's muscular strength and impeding his life. Test for urine proteins was positive for the first time $(1.15 \mathrm{~g} / 24 \mathrm{~h})$. Serum electrophoresis showed a slight hypogammaglobulinemia ( $5 \mathrm{~g} /$ liter). Urine and serum immunoelectrophoresis showed a kappa chain monoclonal component without significant albumin excretion in urines. Polyclonal Ig were slightly decreased in the serum. A first bone marrow cytology showed 6\% of plasmacytes were of normal appearance. The skeletal radiography was normal. The patient was discharged without specific treatment. In September of 1981 the patient's clinical status worsened. He was unable to eat normally due to pharyngeal muscle involvement. A new bone marrow cytology disclosed that $37 \%$ of plasmacytes were of normal appearance. All plasmacytes were positive for intracellular kappa chains and negative for lambda, mu, gamma, and alpha Ig chains with indirect immunofluorescence. Despite a treatment including plasmapheresis (seven cycles) and two cycles of prednisone, melphalan, and cyclophosphamide, the patient died during a stay with his family. An autopsy was not performed.

Two muscle biopsies were performed, in April of 1979 and in November of 1981. Under light microscopy, no extracellular deposit was observed; Congo Red and Thioflavin T stain were negative. On the first biopsy, taken from the deltoid muscle, the ratio and spatial distribution of the muscle fibers were normal. The mean less diameter of the fibers was at the upper limit of the normal values for this age (type I, $55 \mu \mathrm{m}$; type $\mathrm{II}_{\mathrm{A}}, 65 \mu \mathrm{m}$; type $\mathrm{II}_{\mathrm{B}}, 60 \mu \mathrm{m}$ ) (Fig. $2 A$ ). The end-plates structure was normal. On the second biopsy, taken from the quadriceps muscle, there was a marked type I fiber predominance and hypertrophy (mean less diameter, $70 \mu \mathrm{m}$ ), and the type II fibers were slightly atrophic and angulated (mean less diameter, $35 \mu \mathrm{m}$ ). Electron miscroscopy showed a normal myofibrillar organization. A striking finding was a thin fleecy deposit along the plasma membrane of the muscle fibers (Fig. $2 \mathrm{~B}$ ). Numerous coated vesicles contained the same substance. A strong positive stain was observed by immunofluorescence around all muscle fibers using an anti-human kappa light chain antibody (Fig. 2 C). Anti-human lambda, gamma, alpha, and mu antibodies were negative. Anti-human kappa light chain antibody did not reveal a similar deposit in the patient's skin biopsy specimen. Renal biopsy was not performed.

Human sera. The patient's serum was sampled at the beginning of a plasmapheresis $1 \mathrm{wk}$ after the antimitotic treatment was stopped. Its biological effect on muscle cell cultures was compared with that of $(a)$ pooled sera from healthy subjects, $(b)$ serum from a male subject of the same blood group as the patient (group $\mathrm{B}^{-}$), (c) two patients with a kappa light chain myeloma, and $(d)$ a patient with a muscle hypertrophy (Thomsen's myotonia). Each serum was kept frozen at $-80^{\circ} \mathrm{C}$ until used in the cell cultures.

Ig with kappa and lambda light chains were purified from the patient's serum by immunoadsorption on glutaraldehyde-activated ultrogel columns coupled to anti-human kappa and lambda light chain antibodies (Biosys, Compiègne, France) (10). After elution, they were precipitated by dialysis of the eluted peak against $\left(\mathrm{NH}_{4}\right)_{2} \mathrm{SO}_{4}$. The precipitate was 


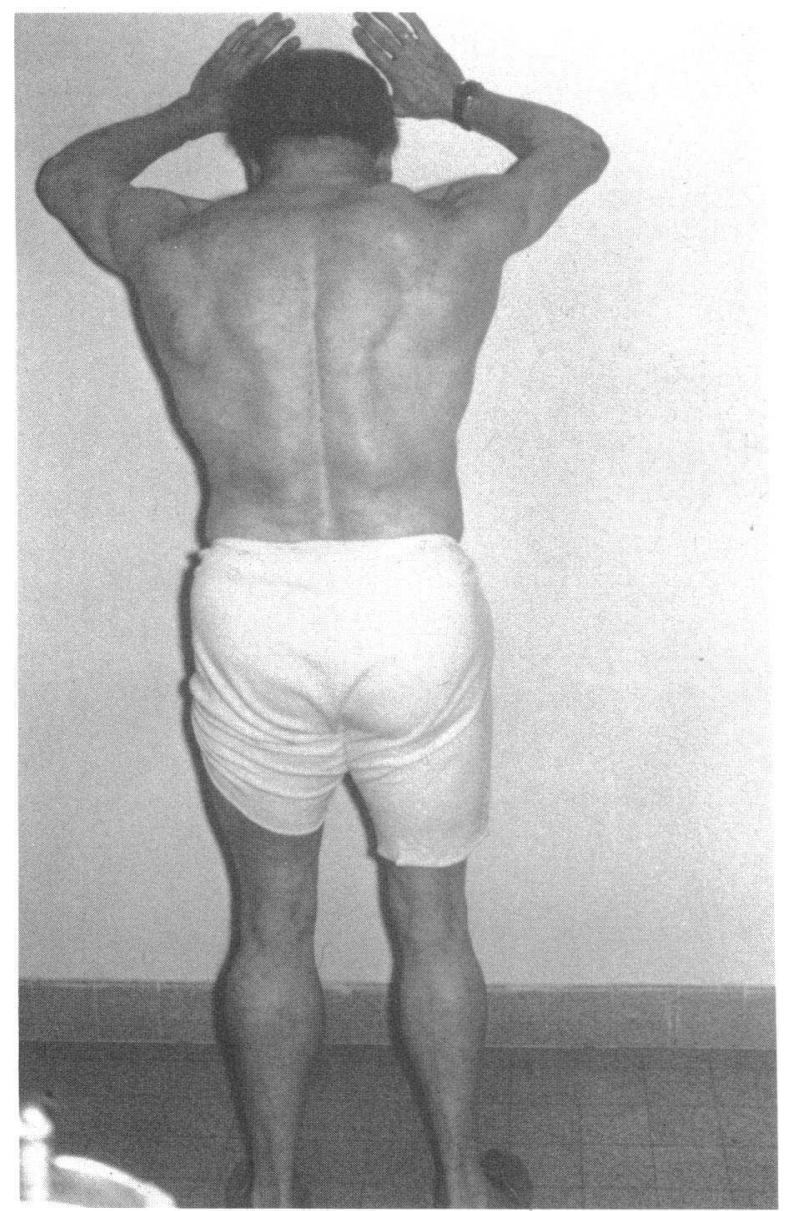

Figure 1. Patient's picture showing the huge hypertrophy of all skeletal muscles.

dissolved in $1 \mathrm{ml}$ culture medium and dialyzed overnight at $4^{\circ} \mathrm{C}$ against $500 \mathrm{ml}$ phosphate-buffered solution, $\mathrm{pH}$ 7.4. The protein content of the eluted peak was then measured by Lowry's technique (11). Its biological activity on the cultured cells was tested at a final concentration of $5 \mathrm{~g} /$ liter.

Muscle cell cultures. The serum effect was tested on human muscle cell cultures in most experiments. The human myoblasts were obtained from muscles of children and adult subjects admitted for orthopedic surgery. The muscle piece was sampled from the quadriceps (vastus lateralis) at the time of surgery. Visible fat and connective tissue were discarded by dissection, while blood cells were removed by washing and teasing the muscle at $4^{\circ} \mathrm{C}$ in calcium-magnesium-free balanced salt solution supplemented with $1 \mathrm{~g} /$ /iter glucose. The tissue was then treated by enzymatic dissociation according to a method described previously (12). Briefly, the dissociating enzyme mixture was $0.07 \%$ trypsin (Gibco, Grand Island, NY) and $0.07 \%$ collagenase (131 U/mg type II; Worthington Diagnostics Div., Millipore Corp., Freehold, NJ) dissolved in balanced salt solution, pH 7.4. $10 \mathrm{ml}$ of this mixture per $100 \mathrm{mg}$ of wet muscle were poured in a stopped Erlenmeyer, which was agitated in a shaking water bath for $30 \mathrm{~min}$ at $37^{\circ} \mathrm{C}$. The supernatant was then removed and the enzyme activity was neutralized by adding fetal calf serum (Gibco). The cell suspension was centrifuged for $10 \mathrm{~min}$ at $1,000 \mathrm{rpm}$ and the cell pellet was resuspended in $1 \mathrm{ml}$ culture medium. Two successive dissociations of $15 \mathrm{~min}$ each were carried out. The three resuspended cell pellets were pooled and filtered to remove the muscle fiber debris. The cells were spread into one or more $25-\mathrm{cm}^{2}$ flasks (Falcon Labware, Oxnard, CA), one flask per $100 \mathrm{mg}$ wet muscle tissue. They were then subcultured to get a sufficient number of myoblasts to allow different experiments on the same culture and to decrease the percentage of fibroblasts present in the primary culture. Almost complete fibroblast re- moval was obtained by successive passages of the cells in a medium (described below) more favorable to the proliferation of myoblasts than of fibroblasts and by using a plastic support on which fibroblasts were grown slowly (Primaria; Falcon Labware). Thus, in this study, only highly myogenic cultures were used, as demonstrated by the high fusion index (90-95\%) measured for each culture. If necessary, the cells were frozen in liquid nitrogen until use.

In two experiments, rat embryo muscle cells were used. Rat embryo muscle cells were obtained from 18-d-old embryos and cultured according to the usual method (13).

The proliferation medium was 78\% Ham's F-12 (Seromed; Biochrom, West Berlin, Federal Republic of Germany), 20\% fetal calf serum, and $2 \%$ chick embryo extract (CEE) ${ }^{1}$ (Flow Laboratories, Irvine, Scotland). The fushion and differentiation medium was $88 \%$ Dulbecco's minimum essential medium (DME, Seromed), 10\% horse serum (Gibco), and 2\% CEE. $100 \mathrm{U} / \mathrm{ml}$ penicillin, $100 \mu \mathrm{g} / \mathrm{ml}$ streptomycin (Seromed) and $5 \mu \mathrm{g} /$ ml Fungizone (E. R. Squibb \& Sons, Princeton, NJ) were added to each medium.

The cultures were maintained at $37^{\circ} \mathrm{C}$ in a humidified $5 \% \mathrm{CO}_{2}$ incubator for 2 or $7 \mathrm{~d}$, according to experiments.

Analytical techniques. Myoblast proliferation was measured by the cell doubling time. For this measure $1.10^{3}$ cells per $2-\mathrm{cm}^{2}$ well (Falcon Labware) were plated. $8 \mathrm{~h}$ after plating, the proliferation medium was removed. The wells were washed three times with Ham's F-12 medium without serum. This medium was then replaced by Ham's F-12 supplemented with $10 \%$ of $(a)$ the serum from the patient, $(b)$ the control human serum and $(c)$ fetal calf serum.

The cells of three different wells for each serum were counted with a calibrated inverted phase contrast microscope each day for $4 \mathrm{~d}$.

Myotube differentiation was studied on cultures grown in the proliferation medium until the phase of myoblast alignment preceding their fusion. As described above, the medium was replaced by DME supplemented with $10 \%$ tested serum. $48 \mathrm{~h}$ after the change of medium, the cultures were fixed by $10 \%$ formol and stained by hematoxilin eosin to measure the fusion index, i.e., the percentage of myoblasts that fused. It was measured by the ratio multiplied by 100 between the number of nuclei located within multinucleated cells and the total number of nuclei present in the same field. Some cultures were grown for $7 \mathrm{~d}$ after changing the medium to observe the cell fusion percentage and the morphology of the myotubes when the cultures reached their maximal differentiation (sarcomeric organization and eventual spontaneous contractions).

The rate of the proteins synthesized by the cultured cells in the presence of the different sera was measured by $\left[{ }^{3} \mathrm{H}\right]$ leucine incorporation into TCA-precipitable material. For this study, $5 \times 10^{4}$ cells were plated in $35-\mathrm{mm}$ tissue culture dishes. They were grown during $24 \mathrm{~h}$ in conditions similar to those used for subcultures and then cultured for $72 \mathrm{~h}$ in DME supplemented with $10 \%$ of the tested material (control serum, pathological serums, and kappa light chains were added to control serum). After washing with serum-free DME, the cells were labeled for $30 \mathrm{~min}$ with 1 $\mu \mathrm{Ci} / \mathrm{ml} \mathrm{L}\left[4-5{ }^{3} \mathrm{H}\right]$ leucine $(1 \mu \mathrm{Ci} / \mu \mathrm{l}, 160 \mathrm{Ci} / \mathrm{mmol})$ in leucine-free DME. The dishes were then washed three times with $2 \mathrm{ml} \mathrm{DME}$ and after removing all visible medium, the cell proteins were precipitated overnight at $4^{\circ} \mathrm{C}$ by $1 \mathrm{ml}$ of $7.5 \%$ TCA. The supernatant was removed by aspiration and the cell precipitate was lysed with $0.5 \mathrm{ml}$ of $1 \mathrm{M} \mathrm{NaOH}$ at $37^{\circ} \mathrm{C}$ for at least $2 \mathrm{~h} .300 \mu \mathrm{l}$ of the cell lysate was added to $2.7 \mathrm{ml}$ scintillation fluid (Ria Luma; Kontron, Zurich, Switzerland) and the samples were counted for ${ }^{3} \mathrm{H}$-radioactivity (14).

\section{Results}

Effect of patient and control serum on growth of muscle cells in culture. When added to the muscle cell culture medium, the patient's serum exhibited a trophic effect on the growth of these cultures, leading to fourfold cell colony growth in the wells con-

1. Abbreviation used in this paper: CEE, chick embryo extract. 

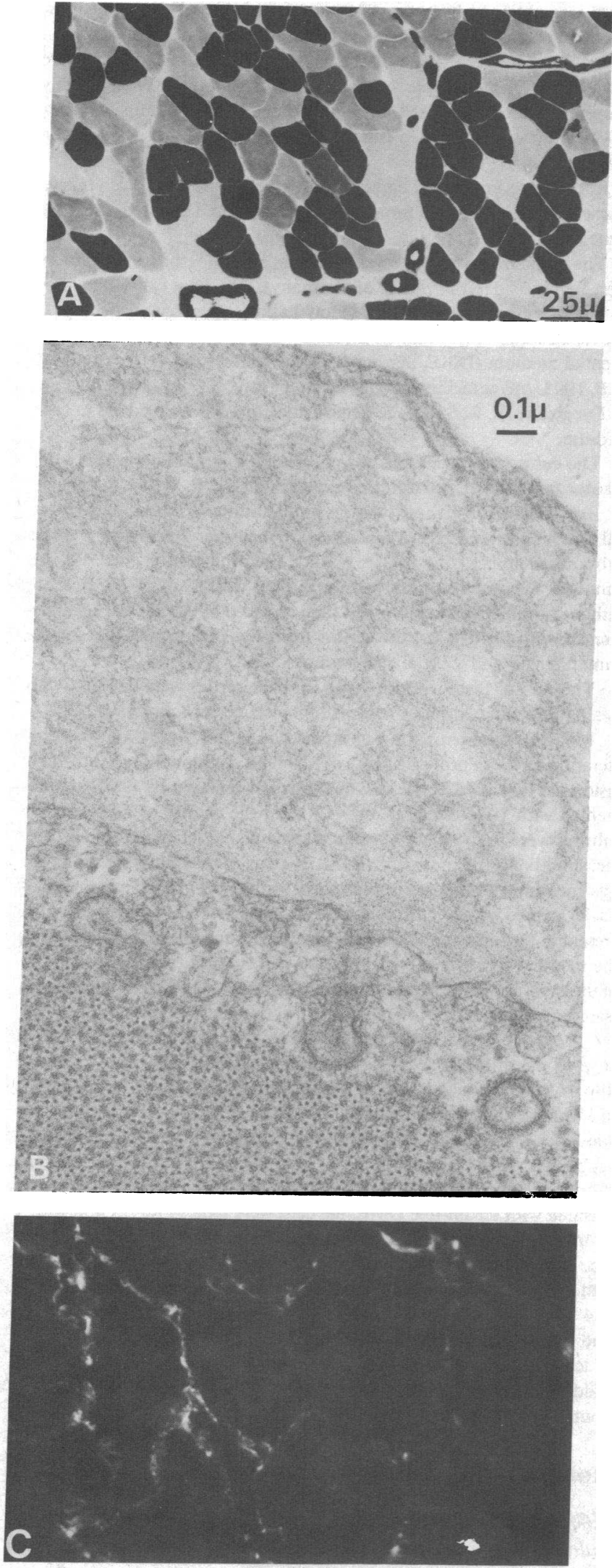

Figure 2. (A) Cryostat section of the muscle; mean diameter of fibers are at the upper limit of normal values. No interstitial deposit was observed by light microscopy. (B) Electron microscopy of muscle showing the thin fleecy deposits along the muscle fiber plasma membrane. Note that pinocytosis vesicles contain the same substance. $(C)$ Trans-

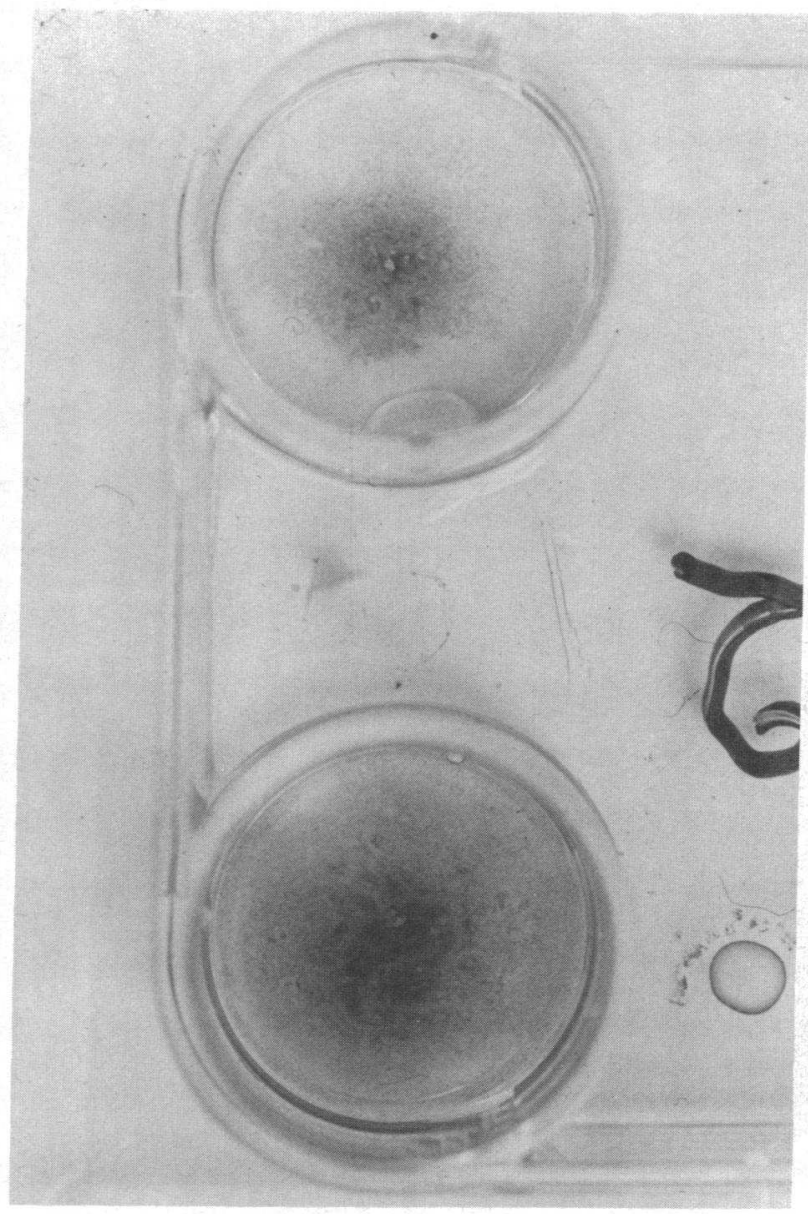

Figure 3. Trophic effect of the patient's serum on human myoblasts plated at the same initial density. In the presence of this serum the cell colony size is fourfold when compared with that of myoblasts grown in the presence of control human serum.

taining the patient's serum compared with control wells (Fig. 3 ). The morphology of the rat myotubes cultured in the presence of the pathological serum was not modified. The growth of the human muscle cells was not modified when cultured in the presence of the serum from the patient with Thomsen's myotonia or in the presence of pooled serum from patients with kappa light chain myeloma but without muscle hypertrophy. On the other hand, the trophic effect appeared specific for myoblasts, since cultures of other cells (human skin fibroblasts, and granulocytic and erythroid bone marrow progenitors) with the patient's serum did not show an effect on the number and the size of these cells.

Effect of the patient's serum on myoblast proliferation. The cells were counted during their phase of exponential growth. The daily cell numeration showed that the rate of the cell proliferation in the presence of the patient's serum was identical to that observed in the presence of the control human serum $(23 \pm 1.30 \mathrm{~h})$. The curves drawn for each culture condition were superimposable. The cell growth velocity in the presence of human serum was lower than that measured in the presence of

verse skeletal muscle cryostat section stained with fluoresceinated antikappa light chain antiserum. A thin linear staining of the sarcolemma was observed with antikappa light chain antiserum. $\times 160$. 
fetal calf serum (population doubling time, $21 \pm 2 \mathrm{~h}$ ), but the difference was not statistically significant.

Effect of the patient serum on myoblast differentiation. The influence of the serum on the cell fusion was measured by the fusion index when the cultures were incubated in the presence of different serums for $48 \mathrm{~h}$ and $7 \mathrm{~d}$. As shown in Table I, after $48 \mathrm{~h}$, the percentage of fused cells in the cultures grown in the presence of the patient's serum was significantly higher than that in the cultures grown in the presence of the control serums. The higher the percentage of fused cells, the lower the density of living cells. In all cultures, a significant negative correlation was found between the total number of nuclei and their percentage present in the myotubes. As the total number of cells varied with the different serums added to the culture medium, the fusion index was also calculated to account for a possible decrease of the cell number at the end of the experiment, in comparison to the control (normal serum). This corrected fusion index of the cultures grown in the presence of the patient's serum remained significantly higher ( $45 \%$ fusion, $62 \%$ nuclei $/ \mathrm{cm}^{2}$ ) when compared with the fusion index (6\% fusion, $100 \%$ nuclei $\left./ \mathrm{cm}^{2}\right)$ of cultures grown with normal serum.

After $7 \mathrm{~d}$, the maximal myotube differentiation was reached. The fusion index of the cultures grown in the presence of the patient's serum was in the same range $(80 \pm 10 \%)$ as that measured in the control cultures. However, the myotube morphology differed significantly. Their width was three or four times greater than that of the normal myotubes; they were so highly branched that they formed a large syncytium with imprecise limits (Fig. 4). On the other hand, small unbranched myotubes containing less than 10 nuclei had about two times the cytoplasm when grown with the patient's serum, compared with control serum.

Effect of the patient serum on protein synthesis. The rate of $\left[{ }^{3} \mathrm{H}\right]$ leucine incorporation into TCA-precipitable material was significantly increased in the cultures grown in the presence of the patient's serum when compared with the values obtained either with the control serum or with the other pathological serums (Table II). On the contrary, the same experiment carried out on two cultures of embryonic rat muscle cells did not show differences in the rate of $\left[{ }^{3} \mathrm{H}\right]$ leucine incorporation between cultures with normal and pathological serums.

Effect of the purified patient's kappa and lambda chain serum Ig. Since the patient's urines were not available, and, following the hypothesis that kappa light chains were responsible for the

Table I. Fusion Index of Human Muscle Cells in the Presence of Different Serums

\begin{tabular}{|c|c|c|c|c|}
\hline \multirow[b]{2}{*}{ Serum } & \multicolumn{3}{|l|}{ No. of nuclei } & \multirow{2}{*}{$\begin{array}{l}\begin{array}{l}\text { Fusion } \\
\text { index }\end{array} \\
\mathrm{N}_{\mathbf{m}} / \mathrm{N}_{\mathrm{t}}\end{array}$} \\
\hline & Total ( $\left.\mathbf{N}_{\mathbf{v}}\right)$ & Myoblasts & Myotubes $\left(\mathrm{N}_{\mathbf{m}}\right)$ & \\
\hline & $\begin{array}{l}1 \times 10^{-3} \\
\times \mathrm{cm}^{2}-1\end{array}$ & $\begin{array}{l}1 \times 10^{-3} \\
\times \mathrm{cm}^{2}-1\end{array}$ & $\begin{array}{l}1 \times 10^{-3} \\
\times \mathrm{cm}^{2}-1\end{array}$ & \% \\
\hline $\mathrm{C}$ & 3 & 2.7 & 0.3 & 10 \\
\hline B- & 2.7 & 2.6 & 0.1 & 4 \\
\hline $\mathbf{H}$ & 2.8 & 2.55 & 0.25 & 9 \\
\hline $\mathbf{M}$ & 2.5 & 2.1 & 0.4 & 8 \\
\hline Patient & 1.7 & 0.5 & 1.2 & 70 \\
\hline
\end{tabular}

$N_{t}$, total nuclei; $N_{m}$, myotube nuclei; $C$, control serum from healthy subjects; $B-$, serum from a male subject of the same blood group (B-) as the patient; $\mathrm{H}$, serum from a patient with Thomsen's muscle hypertrophy; $M$, serum from two myelomatous patients producing kappa light chain Ig but without muscle abnormalities.
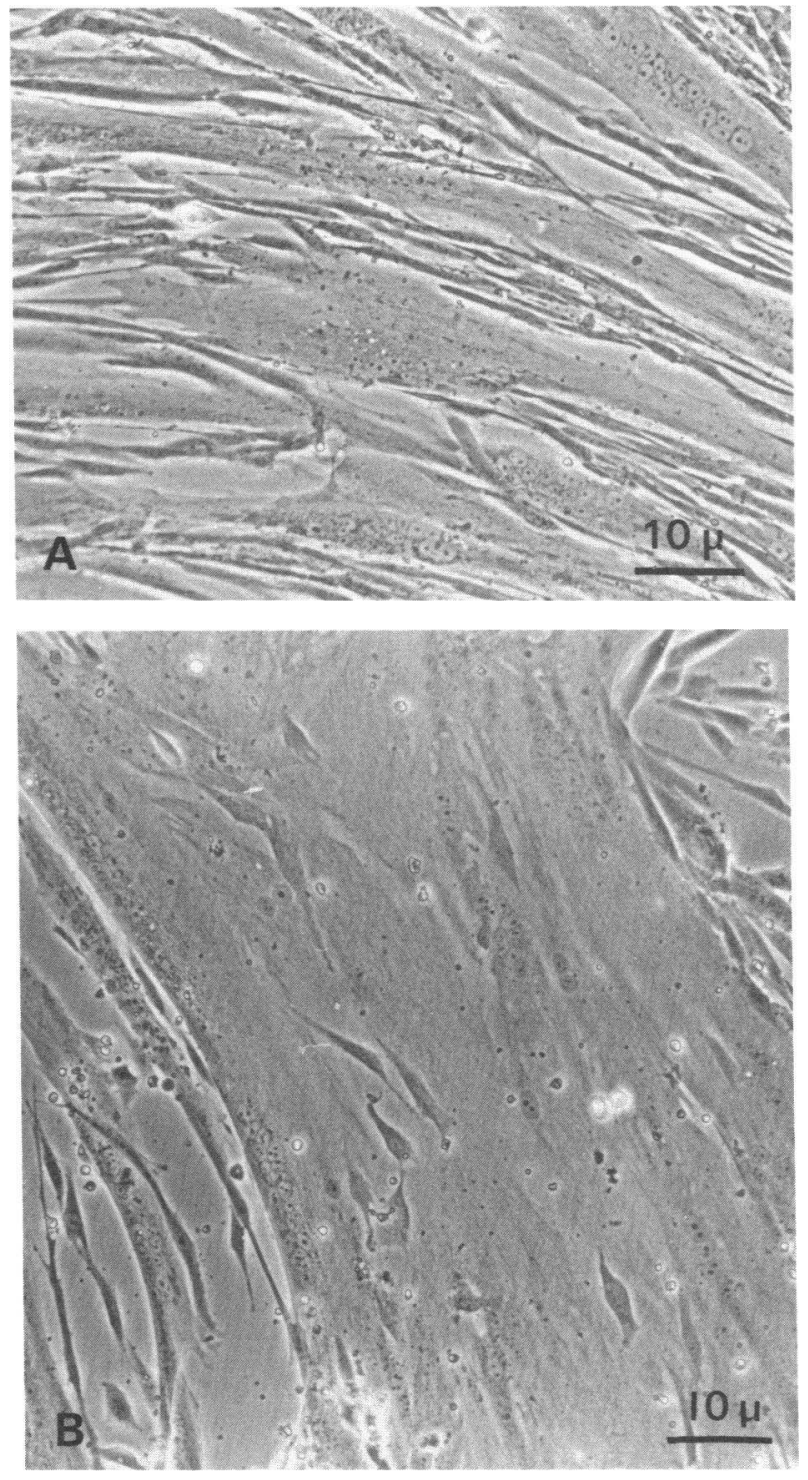

Figure 4. Human myotubes cultured in the presence of control human serum $(A)$ and patient's serum $(B)$. These later myotubes are thick and branched, forming a large syncytium.

myotrophic effect in vitro, patient's kappa and lambda light chain Ig were purified from the serum by immunoadsorption in order to be tested on muscle cell culture. Immunofluorescence study showed that cultured human muscle incubated with patient's serum reacted with anti-kappa but not with anti-lambda and anti-gamma antibodies (Fig. 5). The addition of kappa light chain Ig to control serum induced the same differentiation as

Table II. $\left[{ }^{3} \mathrm{H}\right]$ Leucine Incorporation into TCA-precipitable Material

\begin{tabular}{llll}
\hline Muscle $\quad$ Serum & Control $^{*}$ & Patient & $P$ \\
\hline Human 1 (male, 31 mo) & $36.5 \pm 5.3$ & $63.4 \pm 4.7$ & $<0.001$ \\
Human 2 (male, 42 yr) & $43.1 \pm 2.1$ & $60.0 \pm 3.3$ & $<0.001$ \\
Human 3 (female, 25 yr) & $38.9 \pm 10$ & $73.2 \pm 4.4$ & $<0.01$ \\
Human 4 (female, 5 d) & $49.8 \pm 2.3$ & $70.9 \pm 1.1$ & $<0.001$ \\
Rat fetus & $29.7 \pm 2.6$ & $33.5 \pm 2.4$ & $\mathrm{NS}$ \\
\hline
\end{tabular}

* Pooled sera from healthy subjects. Data expressed in counts per minute per milligram of proteins (mean \pm SEM of six experiments). 
the patient's unfractionated serum. In contrast, the addition of lambda light chain Ig induced the same differentiation as the control serum alone. Furthermore, the cell fusion was accelerated and reached the same percentage $(72 \%)$ as that obtained with the control cultures (Table III). Similarly, the protein synthesis was significantly increased and to the same magnitude as that found for the total patient's serum.

\section{Discussion}

The acquired pseudoathletic morphology observed in this unique patient was apparently due to an increase in the total muscular mass and not to perimuscular deposits. Indeed, in the two biopsies, no interstitial deposit was seen by light microscopy and stains for amyloid deposits were repeatedly negative. The diameter of the muscle fibers was, on the first biopsy, at the upper limit of the normal range for a 62-yr-old man, but it was impossible to determine if this was the result of a recent, progressive process. In the second biopsy, the type I fibers were markedly hypertrophic, but the type II fibers were slightly atrophied, probably in relation to the steroid treatment given to the patient at that time. The fleecy kappa light chain deposit observed by electron microscopy around all muscle fibers may have partially contributed to the production of the hypertrophy. However it was too thin $(1 \mu \mathrm{m})$ to account for the large increase of the muscle mass. The discomfort to the patient resulted mainly from the mechanical consequences of the muscular hypertrophy. Interestingly, the cardiac muscle was not involved.

The discovery, 2 yr after the first muscular symptoms, of a monoclonal proliferation of plasmacytes producing kappa light
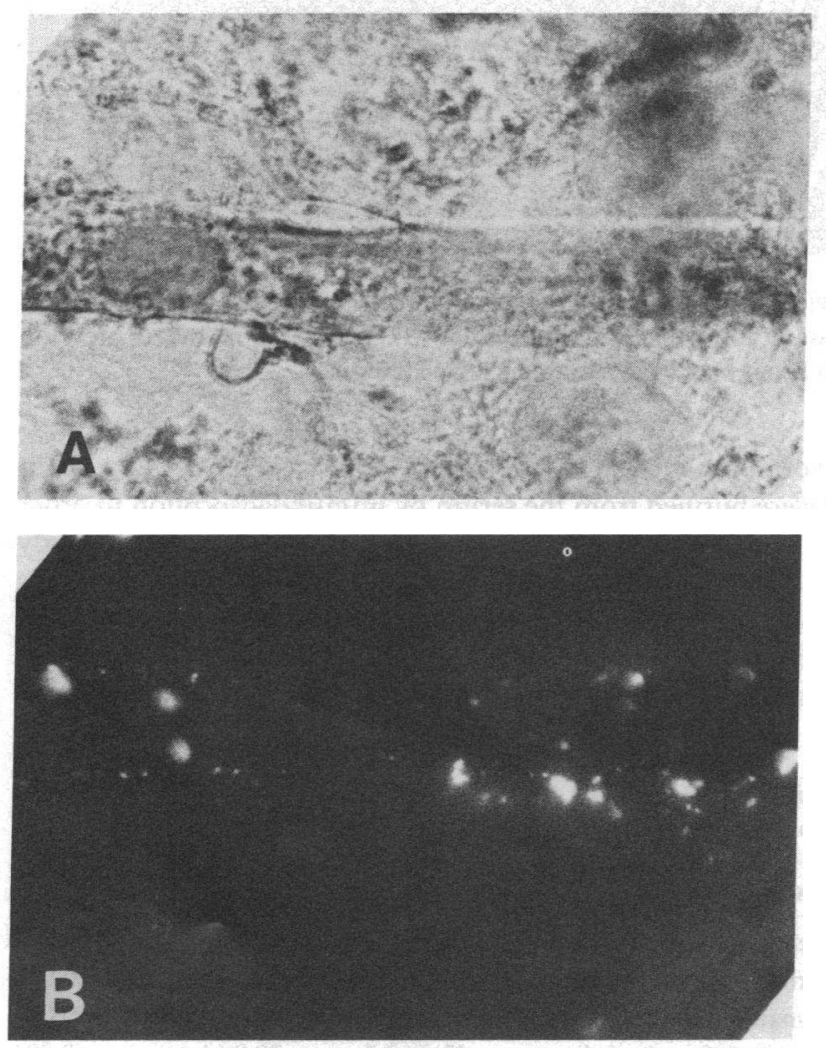

Figure 5. Human myotube incubated with the patient's serum for $1 \mathrm{~h}$ after paraformaldehyde fixation. $(A)$ Phase contrast; $(B)$ immunofluorescence showing the binding of anti-kappa light chain antibodies to the surface of these cells. $\times 500$.
Table III. Effect of the Kappa Ig Immunoadsorbed from the Patient's Serum and Added to Pooled Normal Sera

\begin{tabular}{lll}
\hline Serum & Fusion index & {$\left[{ }^{3} \mathrm{H}\right]$ Leucine incorporation } \\
\hline & $\%$ & $c p m / m g P$ \\
$\mathrm{C}$ & 10 & $22.1 \pm 3.1$ \\
$\mathrm{C}+\kappa \mathrm{Ig}$ & 72 & $64.7 \pm 7.2^{*}$
\end{tabular}

C, pooled control serums; $\mathrm{C}+\kappa \mathrm{Ig}$, control sera and kappa immunoglobulins purified from the patient's serum.

* Value statistically different from the control values (Student's $t$ test, $P<0.001$ ).

Results are expressed as the mean \pm SEM from two triplicate experiments.

chains was the second main finding in this patient. Since amyloidosis was ruled out, the most likely diagnosis was Ig light chain disease. This disease was first described by Randall et al. (15) and further reported by others (16-18). Symptoms include renal, hepatic, and cardiac failures due to Ig light chain deposits. Muscle cell hypertrophy, as shown in our patient, has never been reported. In our patient, kappa light chain deposits were present around the muscle cells and, in light of this, his disease could be classified as another case of Ig light chain disease. However, all usual clinical symptoms of this disease were absent; the kidney, heart, and liver remained apparently unharmed. The deposits of kappa light chains around the muscle cells and not around the other cells, as shown by the patient's skin biopsy and by in vitro studies, suggested that free kappa light chains themselves might support the muscle growth-enhancing activity observed in the patient's serum.

In investigating the hypothesis of a circulating growth factor specific for the muscle cells that is present in the patient's serum and involved in the pathological process, we found muscle cell cultures to be a choice material, since they are disconnected from their own humoral environment and the effects of change in their surrounding medium can be estimated. The experiments performed by adding the patient's serum to cultured human myoblasts showed that this serum had a muscle cell growth activity, which from our experiments on other cells, especially human fibroblasts, appeared specific for human myogenic cells. The responsibility of the abnormally secreted free Ig kappa light chain was strongly suggested by experiments using specifically immunoadsorbed patient's kappa and lambda serum Ig. Indeed the addition of the patient's kappa serum Ig to normal human serum reproduced the effects observed with the patient's unfractionated serum, whereas the patient's lambda serum Ig did not. Although isolated monoclonal kappa chains were not tested, these in vitro data, together with the results of the immunofluorescence study, made it very likely that free kappa chains secreted by the patient's myeloma cells were responsible for the muscular hypertrophy.

This trophic effect could be due either to an increase in cell proliferation or to a higher myotube differentiation. The results of the experiments described in this paper clearly demonstrated that the patient's kappa light chain Ig increased the myotube differentiation through an acceleration of the fusion process and an increase in the protein synthesis. In measuring the increase of the muscle mass, we used $\left[{ }^{3} \mathrm{H}\right]$ leucine, which is an unspecific marker of protein synthesis, instead of more specific markers of muscle proteins (such as creatine kinase, myosin heavy chain, or acetylcholine receptors) for two reasons. First, the cultures used in this study were highly myogenic, minimizing the per- 
centage of proteins synthesized by the nonmyogenic cells. Second, experiments on human fibroblasts showed that the patient's serum did not increase their multiplication and, consequently, did not increase the number of these cells, already sparse at the beginning of the culture. The study of specific muscle proteins will be useful in a second step of experiments to pinpoint the mechanism of action of the patient's serum on muscle cells. This direct action on muscle cell differentiation is unusual. Indeed, the factors known to influence the growth of the muscle cells (fibroblast growth factor, [19] insulin, throxin [20], somatomedin [21], and transferrin [22]) all increase their proliferation. The higher number of myotubes found in the cultures fed with one or many of these factors is the consequence of an increased proliferation of the myoblasts.

The mechanism of action of the patient's kappa light chain on muscle cell differentiation remains to be demonstrated. Indeed, the events triggering the fusion are not clearly understood. The experiments using different culture conditions described in this paper suggest that there is a balance between the myoblast proliferation and the myotube differentiation. Qualitative changes in the culture medium balance this equilibrium. For instance, Ham medium plus fetal calf serum promotes the myoblast proliferation; conversely DME plus horse serum provoked the fusion (see Methods). Studies of avian and mouse myogenesis have suggested that serum and chick embryo extract contain macromolecular components that are inhibitory to differentiation (23). It was demonstrated that the myoblast differentiation occurred rapidly in the cultures fed conditioned medium, i.e., medium collected after having fed a myogenic culture for at least $3 \mathrm{~d}$ and which was, consequently, depleted of mitogens. Conversely, serum and CEE added to the conditioned medium delayed myoblast fusion (24). As myoblasts continue to proliferate in the presence of macromolecular components, the mitogenic activity could be on the same molecule as the inhibiting differentiation components. It is tempting to speculate that the myogenic activity of the free kappa light chains present in the serum of our patient could result in an indirect blockage of the biological properties of the mitogenic-inhibiting differentiation macromolecule(s).

The abnormally numerous coated vesicles located beneath the sarcolemma probably reflect an intense endocytosis process of the Ig deposits surrounding the muscle fibers. Whether this endocytosis has some relationship with the myogenic effect remains speculative. Finally, it is likely that the biologically active portion of these kappa light chains is located on the variable region at its amino terminal end, since sera of three patients with kappa light chain myeloma but without muscular hypertrophy behave like normal human serum on muscle cultures.

\section{Acknowledgments}

We are undebted to to Dr. Fabienne Drouin for helping to collect clinical data, to Dr. F. Picard, Department of Hematology, Hôpital Cochin, Paris, France, for performing immunofluorescence of the plasmocytes, to $\mathrm{Dr}$. Ph. Gambel for reviewing the manuscript, and to Ms. Pascale Guillaumin and Ms. Sylvie Le Bihan for typing the manuscript.

This study was supported in part by a grant from the Association des Myopathes de France.

\section{References}

1. Verret, J. M., and J. Lapresle. 1981. L'hypertrophie musculaire en clinique neurologique. Acta. Neurol. Belg. 81:33-51.
2. Lubarsch, O. 1929. Zur Kenntnis ungewöhnlicher Amyloidablagerungen. Virchows Arch. Pathol. Anat. Physiol. Klin. Med. 271:86789.

3. Mollo, H., and H. Lebell. 1932. Zur Klinik der Systematisierten Amyloidabladgermg. Wien. Arch. Inn. Med. Deren. Grenzgeb. 22:20528.

4. Fisher, J. H., and R. A. Thompson. 1958. Primary amyloidosis. Can. Med. Assoc. J. 78:264-66.

5. Martin, J. J., L. Van Bogaert, J. Vandamme, and J. Peremans. 1970. Sur une pseudo-myopathie ligneuse généralisée par amyloidose primaire endomysio-vasculaire. J. Neurol. Sci. 11:147-66.

6. Lange, R. K. 1974. Primary amyloidosis of muscle. South. Med. J. 63:321-23.

7. Whitaker, J. N., K. Hashimoto, and M. Quinones. 1977. Skeletal muscle pseudohypertrophy in primary amyloidosis. Neurology. 27:4754.

8. Ringel, S. P., and H. N. Claman. 1982. Amyloid-associated muscle pseudohypertrophy. Arch. Neurol. 39:413-417.

9. Delaporte, C., and M. Fardeau. 1984. Effet du sérum d'un malade ayant un myélome et une hypertrophie musculaire diffuse sur la croissance des cellules musculaires humaines en culture. $C$. $R$. Acad. Sci. 298:4954.

10. Khan, A., D. Cottereau, D. Daegelen, and J. C. Dreyfus. 1981. Cell free translation of messenger RNA-s from adult and foetal human muscle. Eur. J. Biochem. 116:7-12.

11. Lowry, O. H., N. J. Rosebrough, A. L. Farr, and A. L. Randall. 1951. Protein measurement with the folin reagent. J. Biol. Chem. 193: 265-75.

12. Delaporte, C., M. Dehaupas, and M. Fardeau. 1984. Comparison between the growth pattern of cell cultures from normal and Duchenne dystrophy muscle. J. Neurol. Sci. 64:149-60.

13. Koenig, J. 1979. Formation and maturation of nerve-muscle contacts in cultured rat embryo cells. Biol. Cell. 35:147-52.

14. Delaporte, C., F. Gros, C. Jonsson, and J. Bergström. 1982. In vitro cytotoxic properties of plasma samples from uremic patients. Clin. Nephrol. 17:247-53.

15. Randall, R. E., W. C. Williamson, F. Mullinax, M. Y. Tung, and W. J. J. Still. 1976. Manifestations of systemic light chain deposition. Am. J. Med. 60:293-99.

16. Preud'homme, J. L., L. Morel-Maroger, J. C. Brouet, M. Cerf, F. Mignon, P. Guglielmi, and M. Seligmann. 1980. Synthesis of abnormal immunoglobulins in lymphoplasmacytic disorders with visceral light chain deposition. Am. J. Med. 69:703-10.

17. Tubbs, R. R., G. N. Gephardt, J. T. McMahon, P. Hall, R. Valenzuela, and D. G. Vidt. 1981. Light chain nephropathy. Am. J. Med. 71:263-69.

18. Linder, J., R. T. Vollmer, B. P. Croker, and J. Shelburne. 1983. Systemic kappa light-chain deposition; an ultra structural and immunohistochemical study. Am. J. Surg. Pathol. 7:85-93.

19. Gospodarowicz, D., J. Weseman, J. S. Moran, and J. Lindstrom. 1976. Effect of fibroblast growth factor on the division and fusion of bovine myoblasts. J. Cell. Biol. 70:395-45.

20. Kumegawa, M., E. Ikeda, S. Hosoda, and T. Takuma. 1980. In vitro effects of thyroxine and insulin on myoblasts from chick embryo skeletal muscle. Dev. Biol. 79:493-9.

21. Ewton, D. Z., and J. R. Florini. 1980. Relative effects of the somatomedins, multiplication-stimulating activity, and growth hormone on myoblasts and myotubes in culture. Endocrinology. 106:577-83.

22. Ii, I., I. Kimura, and E. Ozawa. 1982. A myotrophic protein from chick embryo extract: its purification, identity to transferrin, and indispensability for avian myogenesis. Dev. Biol. 94:366-77.

23. Linkhart, T. A., C. H. Clegg, and S. D. Hauschka. 1981. Myogenic differentiation in permanent clonal mouse myoblast cell lines: regulation by macromolecular growth factors in the culture medium. Dev. Biol. 86: 19-30.

24. White, N. K., P. H. Bomer, D. R. Nelson, and S. D. Hauschka. 1975. Clonal analysis of vertebrate myogenesis IV medium dependent classification of colony-forming cells. Dev. Biol. 44:346-61. 